\title{
Application of GIS in land quality mapping for agricultural planning of Ha Giang Province
}

\author{
Anh Mai Thi Tran 1, Quan Anh Duong 2,*, Thi Quang Nguyen 1, Nhuan Duc Nguyen1, \\ Tuyen Van Ha ${ }^{1}$, Thuy Thu Nguyen ${ }^{1}$ \\ ${ }^{1}$ Faculty of Resource management, Thai Nguyen University of Agriculture and Forestry, Vietnam \\ ${ }^{2}$ Faculty of Geomatics and Land administration, Hanoi University of Mining and Geology, Vietnam
}

\section{ARTICLE INFO ABSTRACT}

Article history:

Received 01 ${ }^{\text {st }}$ Aug. 2020

Revised $20^{\text {th }}$ Nov. 2020

Accepted 31 st Dec. 2020

\section{Keywords:}

GIS application,

Land and evaluation,

Land mapping.

Land quality.
In Vietnam, agriculture development is one of the most important tasks to secure food resources and reduce poverty. The north of Vietnam is the high mountain areas which are in the low development stage, agriculture is the main source of income of households. Ha Giang is a typical mountainous province, in which land management is very important in the development of economic. To get good land management, land evaluation is needed. The land quality evaluation is an important step in the land evaluation process. The paper presents the application of a geographical information system (GIS) and establish the land quality map in Ha Giang province in accordance with the Food \& Agriculture Organization framework. The evaluation process starts from defining the land quality indicators which are in 4 categories: Climatic, Terrain, Soil, and Hydrological. The indicators are standardized and classify according to the FAO land quality evaluation system, all of data is processes in GIS environment, each indicator is a data layer in GIS database. The result is maps of indicators and the land quality map of Ha Giang province. There are 126 land quality units in which, more than half of them are of Feralsol. The result of the study can be used in various fields of management as agriculture, land use, infrastructure development,...

Copyright (C) 2020 Hanoi University of Mining and Geology. All rights reserved.

\section{Introducion}

\subsection{GIS and land quality mapping for agricultural planning}

${ }^{*}$ Corresponding author

E- mail: duonganhquan@humg.edu.vn

DOI: 10.46326/JMES.2020.61(6).05
It is necessary to determine the quality of land units for different agricultural types to adopt the best land-use system because agriculture and land quality have strong interaction (FAO, 1997). Land quality analysis is indeed helpful to find out the suitable land for rainfed farming in Iran (Kazemi and Akinci, 2018), for rubber plantations in Thailand (Ali et al., 2018), for giant prawn farming in Bangladesh (Hossain and Das, 2010), 
for winter wheat in China (Wang, 2011), for wheat with the hybrid system in Turkey (Dedeoğlu and Dengiz, 2019), for various crops and plants involving cashew, cassava, citrus, coconut, coffee, groundnut, maize, paddy rice in West Africa (Dijkerman, 1988), for different Land Utilization Types (LUTs) in Arab (Mazahreh et al., 2019).

Land quality assessment is a systematic process of environmental, social, and economical aspects for land use decision-making. Since 1976, the Food and Agriculture Organization of the United Nations has published a framework for land evaluation. Land suitability is usually described as land utilization types after being assessed and classified concerning specific kinds of use (FAO, 1976). Nowadays, ArcGIS is a common tool in land quality and land suitability analysis (Kazemi and Akinci , 2018). GIS software is used to create land suitability maps for each factor and then combine them by the overlaying technique based on the FAO framework. In most cases, GIS uses a thematic soil map as the base to divide land units. It has some typical advantages of a systematic analysis tool because it considers not only biological factors such as topography, soil, weather, plant factors but also various other criteria combining the socio-economic factors such as market, livelihood (Kazemi and Akinci, 2018), infrastructure facilities (Hossain and Das, 2010). The number of layers is different between studies. In the study in Thailand, there were 12 layers including rainfall, slope, elevation, $\mathrm{pH}$, soil drainage, soil depth, soil nutrients, soil texture, distance to the road, distance to the factory, population density, and available land use map (Ali et al., 2018). In a study in Turkey, they selected only 10 factors to include physical, chemical, and topography (Dedeoğlu and Dengiz, 2019).

The FAO framework for land quality assessment has been applied in previous projects in Vietnam (Lefroy et al., 2000; Nguyen and Shrestha, 2008; Pham et al., 2018; Nguyen et al., 2018; Lam et al., 2020). In this study, the land quality i evaluated by using GIS concerning the soil, climate, topography, and hydrological factors to create land quality maps. This study aimed to use MCDM in a GIS environment to clasfify the suitability rating of criteria to gain a database for land-use suitability layers for the land quality unit, also to optimize land use alternatives and therefore to improve agricultural production.

\section{Data and Methodology}

\subsection{Study area}

Ha Giang is the mountainous province with the complex topography and climatic conditions in the north of Vietnam with administrative boundary as Figure 1. It has Dong Van plateau with the elevation ranges $1,300 \div 1,400 \mathrm{~m}$ a.s.l with 90\% calcium mountains belongs to Quan Ba, Yen Minh, Dong Van, Meo Vac. Besides, it has a high number of rivers and streams with an area of approximately 8,000 ha, account $0.97 \%$. The river system includes Lo, Chay, Gam, Nho Que, Mien, Bac, Chung. The total area of Ha Giang is about $792,948.34$ ha. The agricultural land occupies $637,431.09$ ha, however, it is currently fragile and severely degraded, poor nutrient, acid, permanently dry due to the high elevation with the steep slope and mismanagement of natural resources. The elevation ranges between $80 \mathrm{~m}$ a.s.l and 2,419 $\mathrm{m}$ a.s.l.

In Ha Giang, the climate is characterized by 4 microclimate (northwest, northeast, Center, and south - region 1,2,3,4, respectively) with two main seasons (dry and rainy seasons). The microclimate region 1 and 2 are the most common with 521.3 ha accounted for by $36.07 \%$ of the natural provincial area. The average daily temperature ranges from $22^{\circ} \mathrm{C}$ to $24^{\circ} \mathrm{C}$. The lowest temperature is in winter during January, November, and December. The hottest time is in summer during July, August. The mean air humidity is about $85 \%$. The precipitation is around $2,000 \div 3,000 \mathrm{~mm}$ leading flooding in the rainy season between May and October. To forecast and collect the weather information, 4 meteorology stations are observing 4 main climatic elements temperature, rainfall, humidity, solar radiation in the region namely $\mathrm{Ha}$ Giang, Bac Me, Bac Quang, Hoang Su Phi since 1960 (People's Committee of Ha Giang Province, 2018).

\subsection{Data collection}

1,872 soil profiles were investigated for 6 main soil types ( see Table 2) in Ha Giang province. The location of different soil profiles 


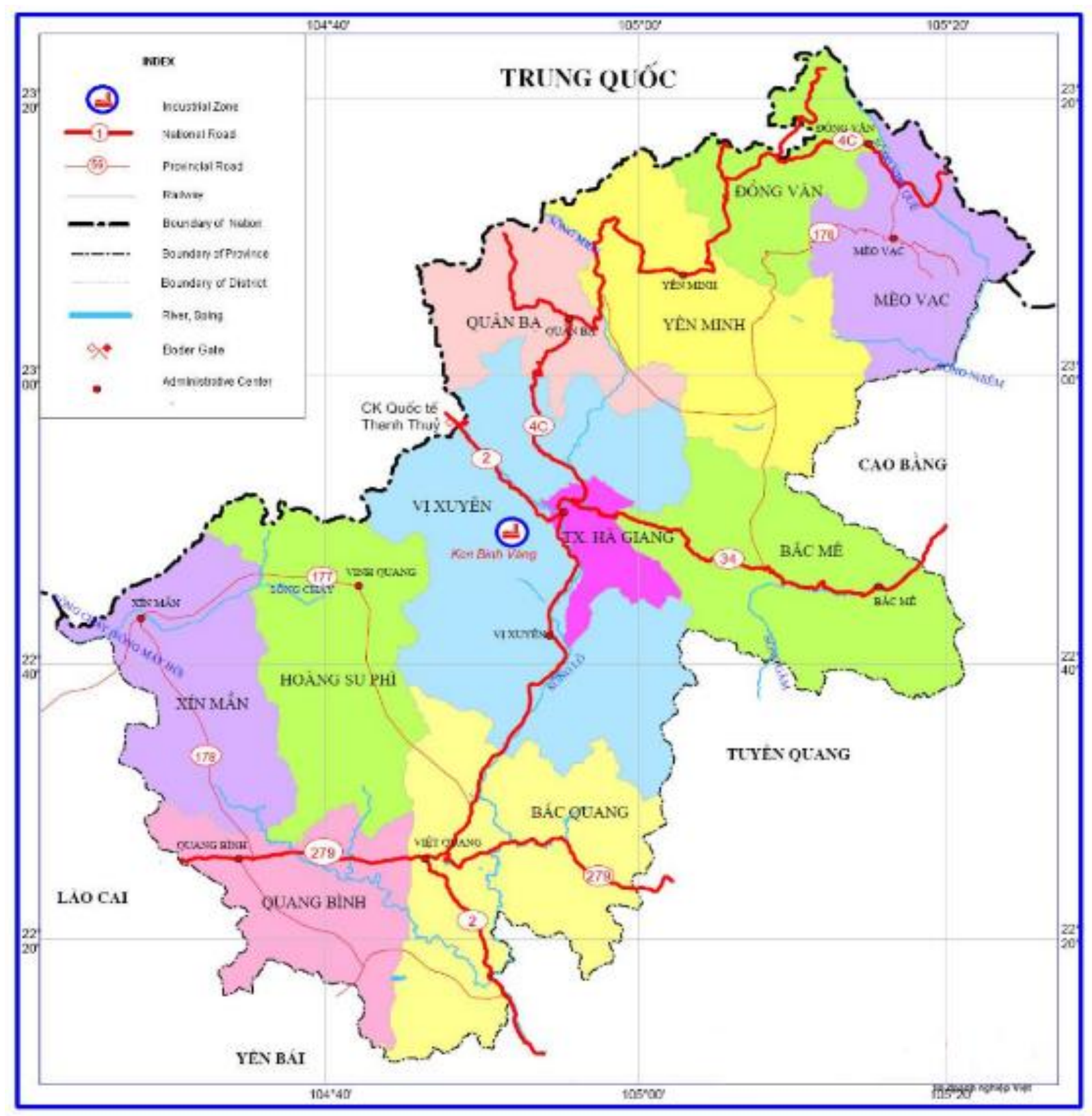

Figure 1. Ha Giang province.

was based on the local soil map. The number of soil profiles 480 ha/ 1 soil profile (For the map scale $1 / 100,000)$. In the flat area, the profile is dug at the center while in the hill or sloping area the soil profile is dug at the top of the slope side of the hill. For each type of soil type, at least 1 main soil profile, 1 sub-main soil profile, and 1 survey soil profile are needed to collect. Soil profiles are generally digging about $125 \mathrm{~cm}$ from the surface to the bottom until touching the hard bedrock or parent material. Soil samples are taken to analyze following TCVN 4046:1985 (Table 1).
Table 1. Soil samples analysis standard.

\begin{tabular}{|c|c|c|}
\hline No & Factors & Methods \\
\hline 1 & pHKCL & TCVN 6862 - 2000 \\
\hline 2 & OM (\%) & TCVN 6822 - 2000 \\
\hline 3 & Total N (\%) & TCVN 6498 - 1999 \\
\hline 4 & Total P (\%) & TCVN 8940 - 2011 \\
\hline 5 & Total K (\%) & TCVN 8660 - 2011 \\
\hline 6 & CEC (cmol + kg/đất) & TCVN 4620 - 1988 \\
\hline 7 & Soil texture & $\begin{array}{c}\text { Pipet (TCVN 5257 - } \\
1999)\end{array}$ \\
\hline
\end{tabular}


The Ferasols soil is the most common in $\mathrm{Ha}$ Giang province while the fluvisol soil is less than that mostly near the flat area, with the slope less than 30. Fluvisol soil, the total area is about 544 ha, account $0.07 \%$ the provincial area, located mostly in Bac Me and Vi Xuyen district. Most fluvisol soil profiles have 4 layers. The soil surface layer has a thickness of about $20 \mathrm{~cm}$ in light brown color, has lots of roots. The second layer has a darker brown color, the structure is platy with less number of roots than the soil surface layer. The third and fourth layers have no roots and the color change to dark grey. Soil is quite base. Soil organic matter ranges from poor to rich. Total Potassium is medium. Nitrogen total ranges from medium to rich. The typical fluvisol profile is CVX33. The humic acrisol soil is only located in the highest region and slope $>250$.

\subsection{Methodology of land quality evaluation}

Land quality indicators are widely used in FAO guidelines for Land management (FAO, 2007). Based on the FAO Guideline, this research proposed a workflow which is described in Figure 2.

\subsubsection{Land quality indicator selection}

The land quality indicators are selected based on the suggestion of (FAO, 1997; Land Quality Indicators: Aspects of Land Use, Land, Soil and Plant Nutrients" The indicators consist of 5 groups: Soil, topography, climate, hydrological conditions, and land use.

Soil indicators: include soil type, soil depth and soil fertility.

In Ha Giang, there are 22 types of soil divided in 6 groups (Table 2) and distributed as Figure 3.

The soil depth is variable from 0 to $>100 \mathrm{~cm}$, in Ha Giang, the soil depth can be classified into 3 classes: $>100 \mathrm{~cm}, 50 \div 100 \mathrm{~cm}$ and $<50 \mathrm{~cm}$.

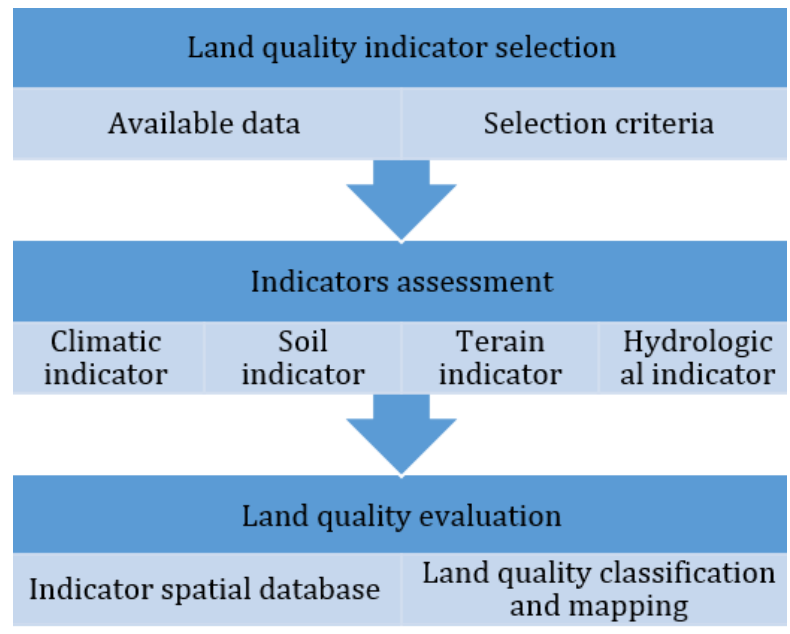

Figure 2. Land quality evaluation process.

The soil fertility is combination of 5 subcriteria: Nutrient (N, P, K,OM), Texture, $\mathrm{PH}$, Cation exchange capacity and Soil compactness.

All of criteria and sub-criteria present as layers of soil data.

Topogaphical indicator: the indicators based on slope as following classification: $0 \div 30,3 \div 8$, $8 \div 15^{0}, 15 \div 25^{0},>25^{0}$.

Climatic indicators include yearly rainfall, total annual temperature (TAT), and dry season length.

Hydrological conditions include irrigation regime which are consist irrigation, semiirrigation and rainfed; drainage conditions with sub-criteria as: heavy flood, moderate flood, low flood and no flood area.

\subsubsection{Indicator assessment}

The indicators are evaluated by using GIS techniques for processing data. The soil indicators are evaluated from soil samples in the study area. The soil samples are used in the soil mapping process. The information in the soil map is extracted and classify based on indicators classification.

Table 2. Soil types and groups in study area.

\begin{tabular}{|c|l|c|}
\hline Group & \multicolumn{1}{|c|}{ FAO/UNESCO } & Vietnamese - soil map \\
\hline G1 & $\begin{array}{l}\text { Dystric Fluvisols, Eutric Fluvisols, Orthi-Thioni-Dytric Fluvisols, Plinthi- } \\
\text { Umbric Fluvisols, Umbric Fluvisols }\end{array}$ & Pc, P, Pc-l, Pu-l, Pu \\
\hline G2 & Haplic Luvisols, Ferric Luvisols, Gleyic Luvisols & Rh, Rfe, Rg \\
\hline G3 & Rhodic Ferralsols, Xanthic Ferralsols & Fk, Fv, Fs, Fa, Fq, Fp, Fl \\
\hline G4 & Haplic Acrisols, Ferralic Acrisols, Gleyic Acrisols, Plinthic Acrisols & Hn, Hv, Hs, Ha, Hq \\
\hline G5 & Alisols & A \\
\hline G6 & Umbrisols, Histosols, Gleysols & D, T, GL \\
\hline
\end{tabular}




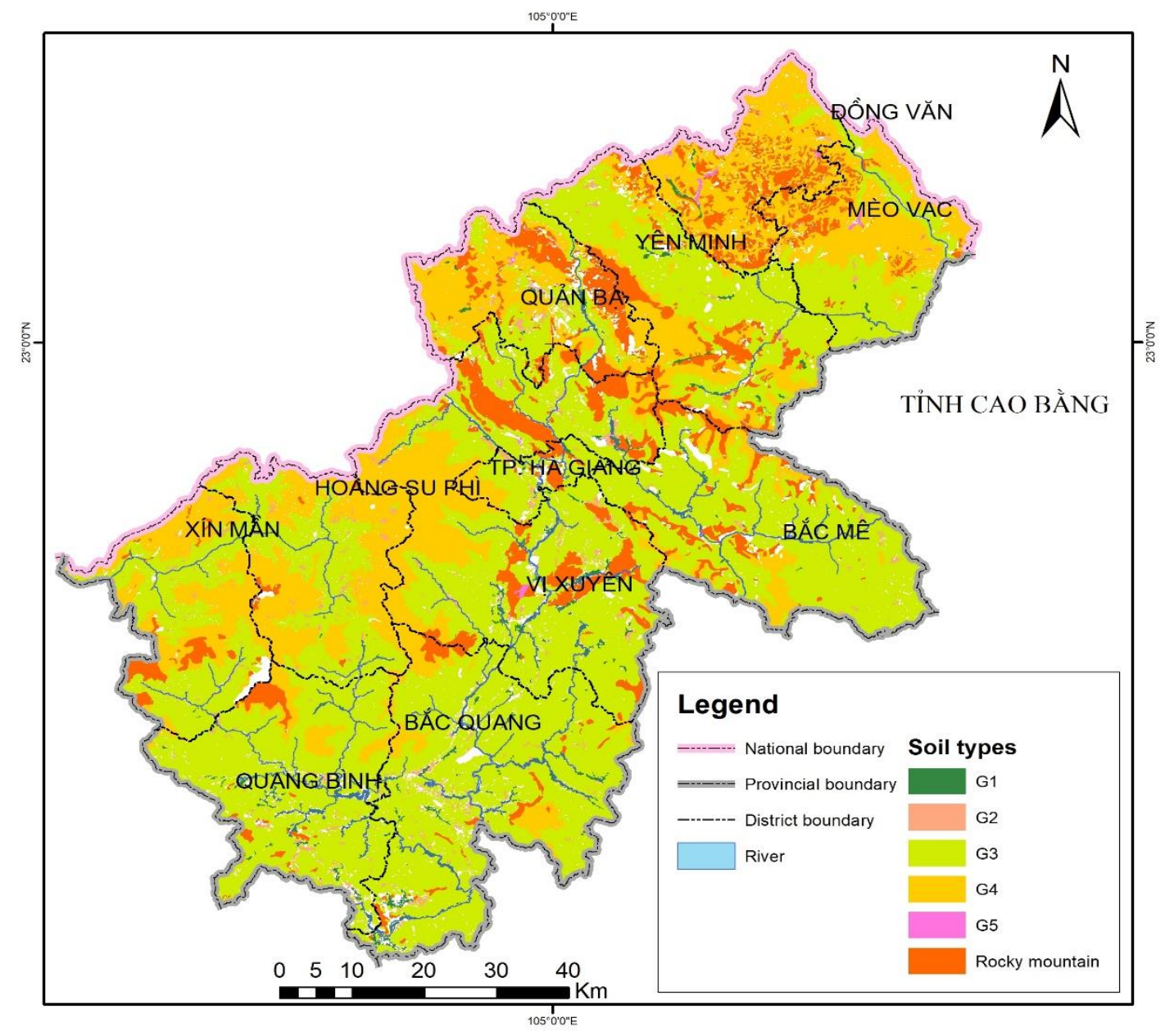

Figure 3. Soil types.

The Topographic indicator is evaluated by using the average slope which is delivered from DEM (cell-size is $30 \mathrm{~m}$ ) and present as Figure 6. The Climatic condition indicator is assessed by using climate data from the surrounding study area. All data are interpolated and classified using GIS processing. The result is climate condition maps. The irrigation indicator is investigated from irrigation reports collected from the Ha Giang DARD office. The indicators are present as the map of irrigation conditions.

\subsubsection{Land quality evaluation}

The land quality is evaluated by combining 4 of those indicators in GIS. 4 layers of data which are stored in a geodatabase and overlayed in the spatial analysis tool of GIS software. After overlay, the data is classified by using the following table of classification (Table 3) as (FAO 2007) suggession. The land quality unit is classified based on suggestion of (MONRE, 2015).

\section{Result and discussion}

\subsection{Indicators}

\section{Soil indicator}

The soil area is investigated in the study area approximated about 750,000 ha occupied $95 \%$ of the nature area. Soil indicators are evaluated, and the result showed in the following figures (Figures 4 and 5).

The result shows that Feralsol is the most common type of soil that occurred in the study area which is occupied about $60.9 \%$ of land area, the second group is Acrisol which is appeared in $25 \%$ of total area. The fertility indicator shows $23.4 \%$ is Low fertility, $64.8 \%$ is Moderate and $11.8 \%$ is High fertility. 
Table 3. Indicator classification.

\begin{tabular}{|c|c|c|}
\hline Indicators & Characteristic & Class \\
\hline \multirow{3}{*}{ Soil } & Soil depth $>50 \mathrm{~cm}$ and fertility $>=$ average. & High \\
\hline & Soil depth $>50 \mathrm{~cm}$ and fertility $<$ average. & Moderate \\
\hline & Soil depth $<50 \mathrm{~cm}$ and fertility <average. & Low \\
\hline \multirow{3}{*}{ Topographical } & $0 \div 8^{0}$ & High \\
\hline & $\geq 8 \div 15^{0}$ & Moderate \\
\hline & $\geq 15^{0}$ & Low \\
\hline \multirow{3}{*}{ Climatic } & $\begin{array}{l}\text { Rain fall }<2,000 \mathrm{~mm} \text {, total temperature } 6,000 \div 7,000^{\circ} \mathrm{C} \text { and dry season from } 3 \div 5 \\
\text { months }\end{array}$ & Low \\
\hline & Rain fall $<2,000 \mathrm{~mm}$, total temperature $>6,000^{\circ} \mathrm{C}$ and dry season from $2 \div 3$ months & Moderate \\
\hline & $\begin{array}{c}\text { Rain fall } 2,000 \div 3,200 \mathrm{~mm} \text {, total temperature } 6,000 \div 7,000^{\circ} \mathrm{C} \text { and dry season }<3 \\
\text { months } \\
\text { Rain fall }>3,200 \mathrm{~mm} \text {, total temperature }>7,500^{\circ} \mathrm{C} \text { and no dry season }\end{array}$ & High \\
\hline \multirow{3}{*}{ Hydrological } & No flood and irrigation & High \\
\hline & No flood and semi - irrigation & Moderate \\
\hline & No flood and rainfed & Low \\
\hline
\end{tabular}

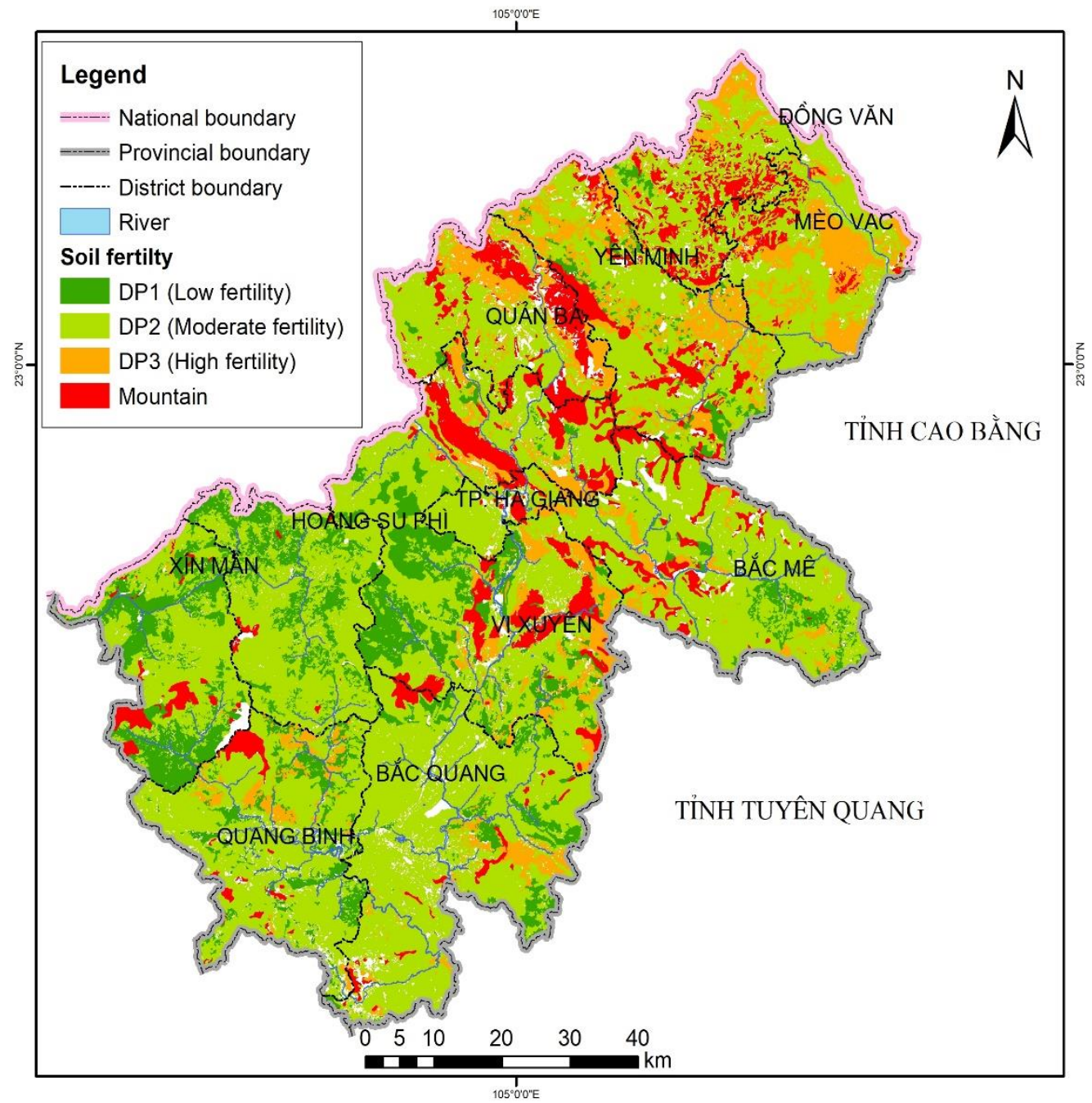

Figure 4. Soil fertility. 


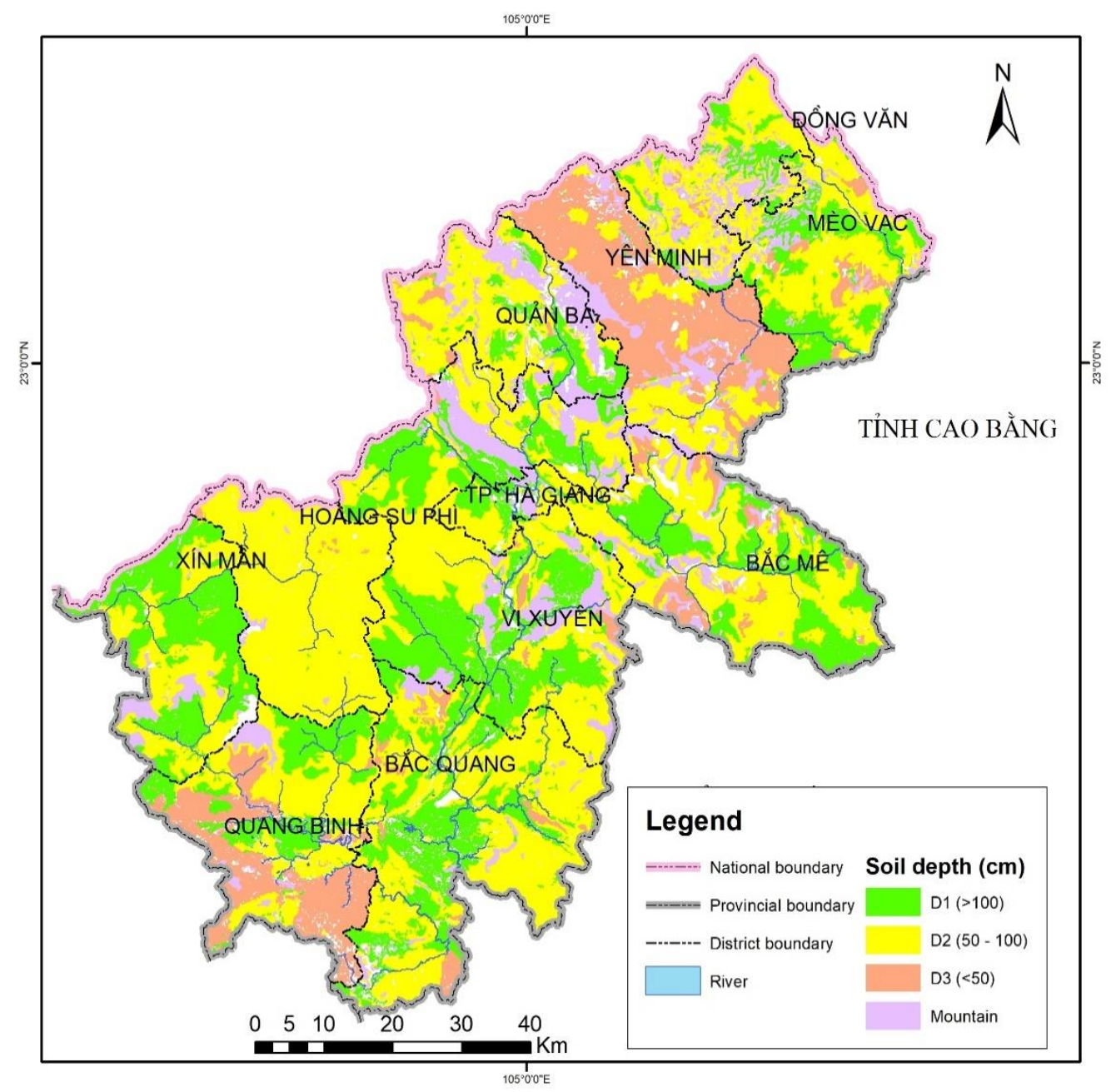

Figure 5. Soil depth.

The Topographical indicator is presented by the slope as following Table 4 and Figure 6.

The result shows that the slope in the study area is very steep, $56 \%$ of the area has a slope steeper than 26 degrees.

The Climatic indicator has been combined and result shows as below (Table 5) and Figure 7:

There are 4 sub-zones in the climatic indicator map, the first sub-zone has $<2,000 \mathrm{~mm}$ rainfall, total temperature $<6,000^{\circ} \mathrm{C}$ and the dry season is $2 \div 3$ months, it occupied 183,669 ha in the North/North-East part of the study area.

The second zone has rainfall in the range of $2,000 \div 3,200 \mathrm{~mm}$, the total temperature is from $6,000 \div 7,500^{\circ} \mathrm{C}$, the dry season is $2 \div 3$ months. This sub-zone stayed in the Center and South part of the study area.
The third one has rainfall $<=2,000 \mathrm{~mm}$, total temperature from $6,000 \div 7,500^{\circ} \mathrm{C}$, and the dry season from $3 \div 5$ months. This zone is in the West part of the study area.

The last sub-zone has rainfall $>3,200 \mathrm{~mm}$, total temperature $>7,500^{\circ} \mathrm{C}$ and dry season $<2$ months. This is in the center part of the study area.

The Irrigation and drainage indicator result is present by Table 6 and Figure 8 :

The result shows that most of the land area in Ha Giang is rainfed, the total rainfed area is $~ 92 \%$, there are only about $2 \%$ is irrigated. The heavy dependence on rainfall is one of the most challenges in agriculture development in this province.

The Figure 8 shows that almost of the area is rainfed, there are only some valleys in Vi Xuyen and Bac Quang has an irrigation system. 
Table 4. Topographical indicator.

\begin{tabular}{|c|c|c|c|c|c|c|c|}
\hline \multirow{2}{*}{ No } & \multirow{2}{*}{ Land group } & \multicolumn{5}{|c|}{ Slope } & \multirow{2}{*}{ Total area(ha) } \\
\cline { 2 - 7 } & & $0 \div 3^{0}$ & $>3 \div<8^{0}$ & $\geq 8 \div<15^{0}$ & $\geq 15 \div<25^{0}$ & $\geq 25^{0}$ & \\
\hline 1 & G1 & 10,667 & & & & & 10,667 \\
\hline 2 & G2 & 5,530 & 2,409 & 246 & 1,811 & 467 & 10,463 \\
\hline 3 & G3 & 2,394 & 9,634 & 43,695 & 161,214 & 235,048 & 451,985 \\
\hline 4 & G4 & 38 & 1,401 & 5,482 & 59,808 & 134,250 & 200,979 \\
\hline 5 & G5 & 216 & 575 & 138 & & & 929 \\
\hline 6 & G6 & & & & & 75,523 & 75,523 \\
\hline \multicolumn{2}{|c|}{ Investigated } & 18,845 & 14,019 & 49,561 & 222,833 & 445,288 & 750,546 \\
\hline
\end{tabular}

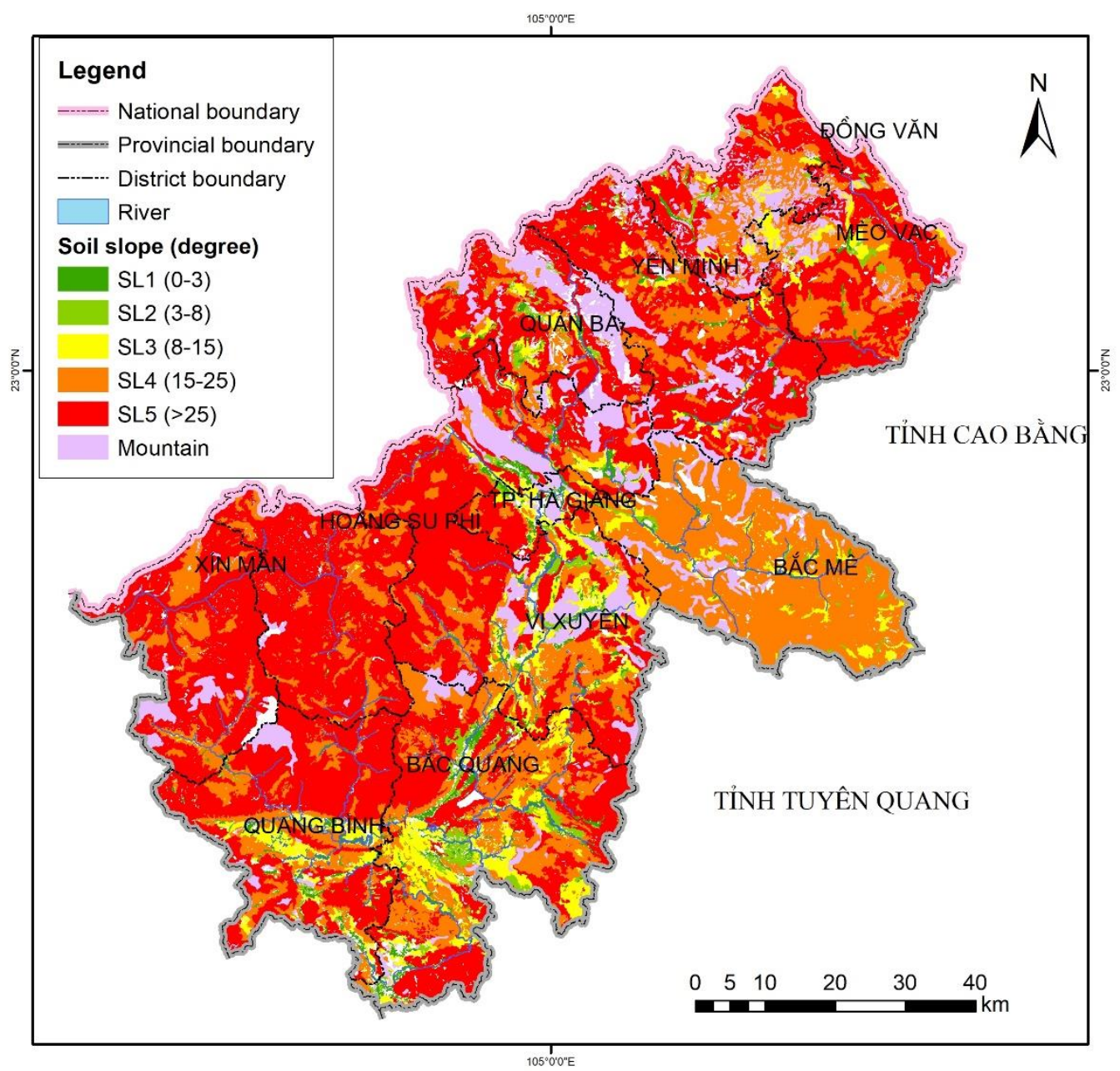

Figure 6. Topographic indicator.

Table 5. Climatic indicator.

\begin{tabular}{|c|c|c|c|}
\hline No & Climatic Sub-zone & Area (ha) & $\%$ \\
\hline 1 & Sub-zone 1 & 235,387 & 29.68 \\
\hline 2 & Sub-zone 2 & 286,058 & 36.07 \\
\hline 3 & Sub-zone 3 & 191,157 & 24.11 \\
\hline 4 & Sub-zone 4 & 37,944 & 4.79 \\
\hline \multicolumn{2}{|c|}{ Investigated area } & 750,546 & \\
\hline
\end{tabular}

Table 6. Irrigation and drainage indicator.

\begin{tabular}{|c|c|c|c|}
\hline No & Hydrological & Classification & Area (ha) \\
\hline \multirow{2}{*}{1} & \multirow{2}{*}{ Irrigation } & Rainfed & 727,477 \\
\cline { 3 - 4 } & & Semi-irrigation & 8,075 \\
\cline { 3 - 4 } & & Irrigation & 14,994 \\
\hline 2 & Drainage & No flood & 750,546 \\
\hline
\end{tabular}




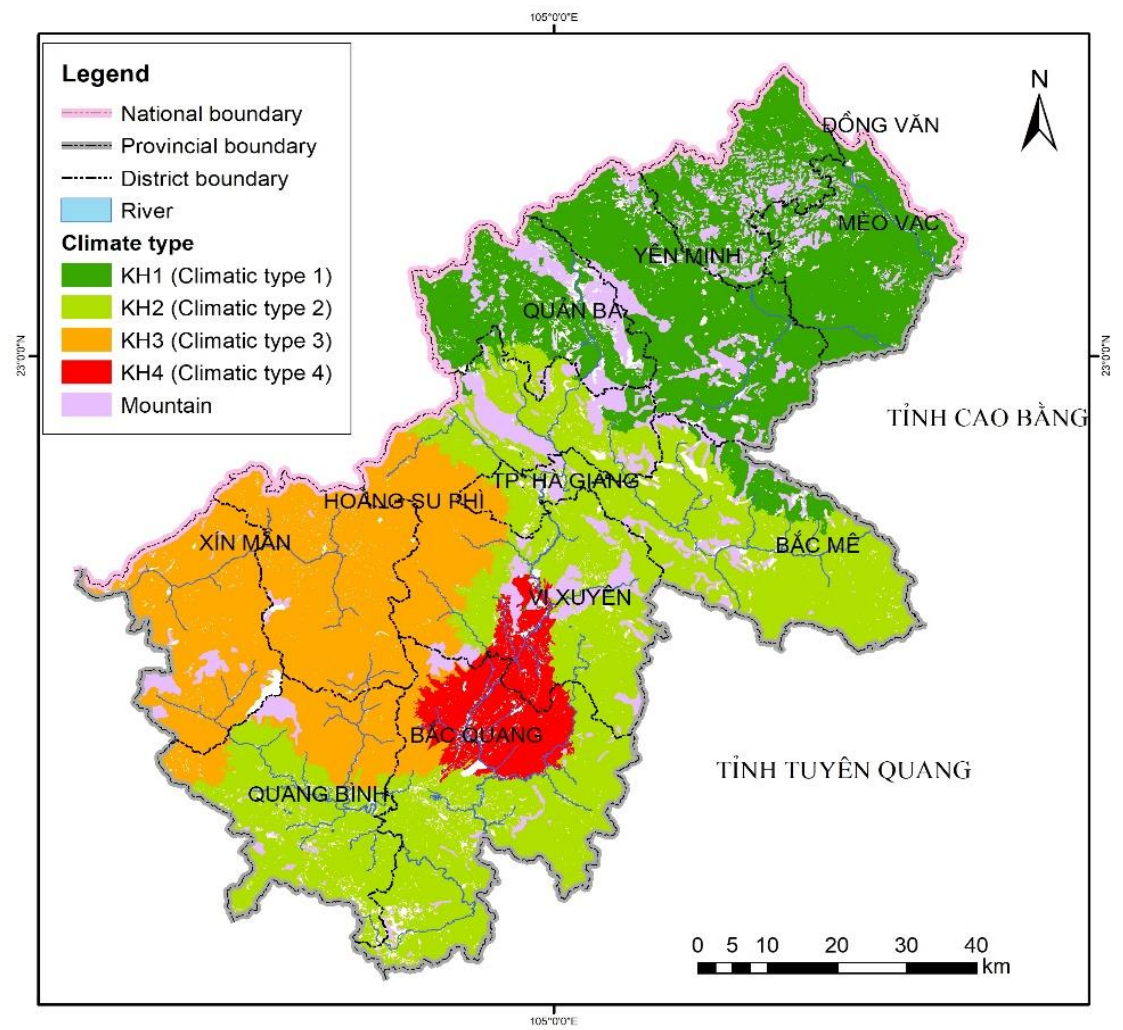

Figure 7. Climatic indicator.

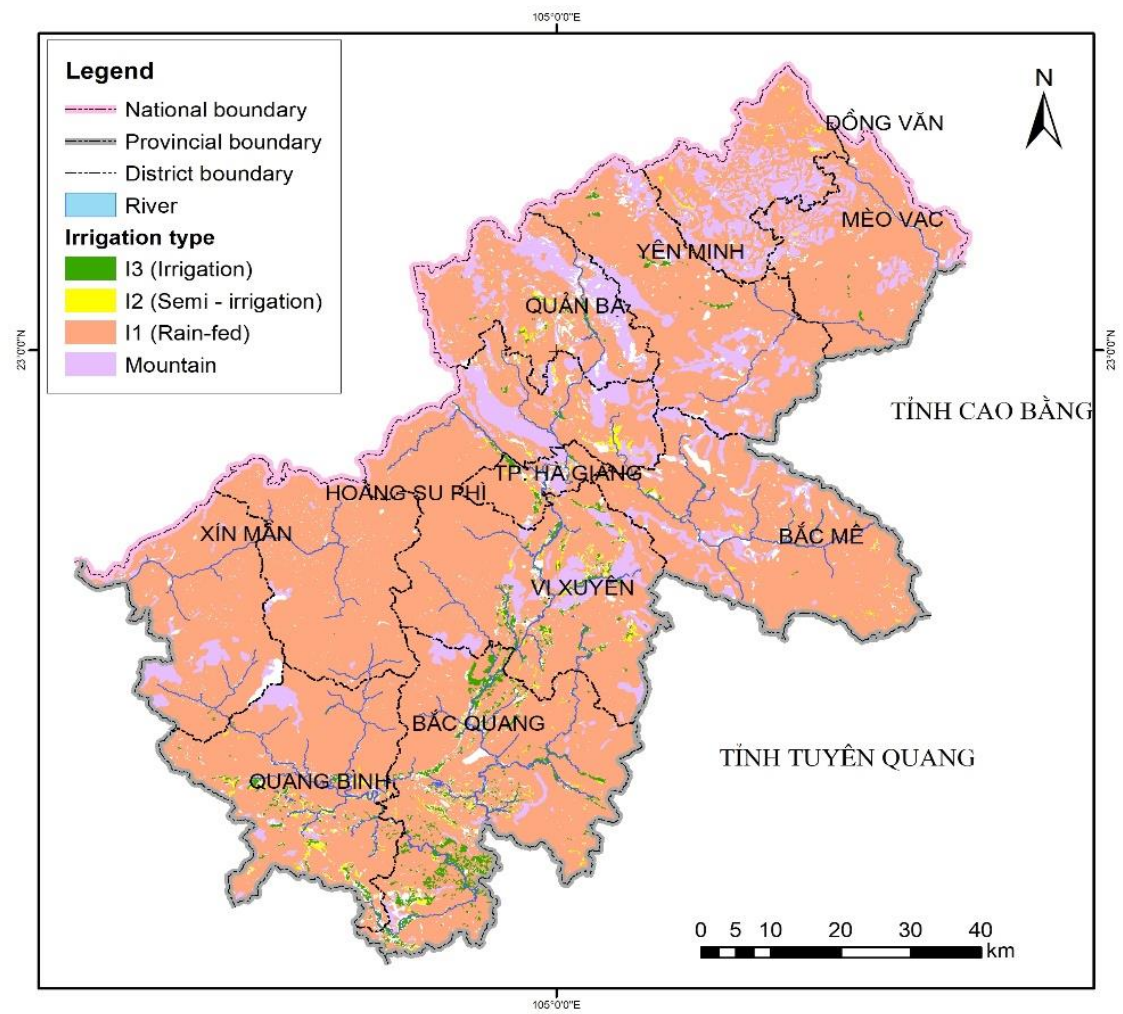

Figure 8. Hydrological condition. 


\subsection{Land quality evaluation}

The land quality indicator is combined in GIS and the result is a map of land quality (Figure 9) and Table 7.

Table 7. Land quality evaluation.

\begin{tabular}{|c|c|c|c|}
\hline No & Land quality class & Area (ha) & $\%$ \\
\hline 1 & High & 56,760 & 7.16 \\
\hline 2 & Moderate & 437,264 & 55.14 \\
\hline 3 & Low & 180,999 & 22.83 \\
\hline & Rock and mountains & 75,523 & 9.52 \\
\hline
\end{tabular}

The high-quality area is 56,760 ha, equal to $7.16 \%$ of the nature area. This type of land quality occurred in Bac Quang (20,697 ha), Vi Xuyen (17.952 ha). This type includes the irrigated area with $>50 \mathrm{~cm}$ soil depth and fertility from moderate to high, mostly rice cultivation $(15,789$ ha) and productive forest (15,724 ha).
The moderate quality is 437,264 ha, occupied $55.14 \%$ of the total area. Most of those areas are using in forestry (productive and protection forest). Some of them are using in annual crop cultivation and unused land. The low quality is 180,999 ha or $22.83 \%$ of the total area. Most of them are protected forests and productive forests.

There are 132 land quality units with 22 of Fluvisol, 28 of Paddy rice Feralsol, 58 units of Feralsol and 20 units of Acrisol on mountainous area, the rest has occurred in other limited soil types.

The land quality evaluation is very important in the land evaluation process. This is a crucial step in agriculture development planning. Ha Giang is a poor province in Vietnam, the land quality and land evaluation should play an important role in economic development and cultivation planning.

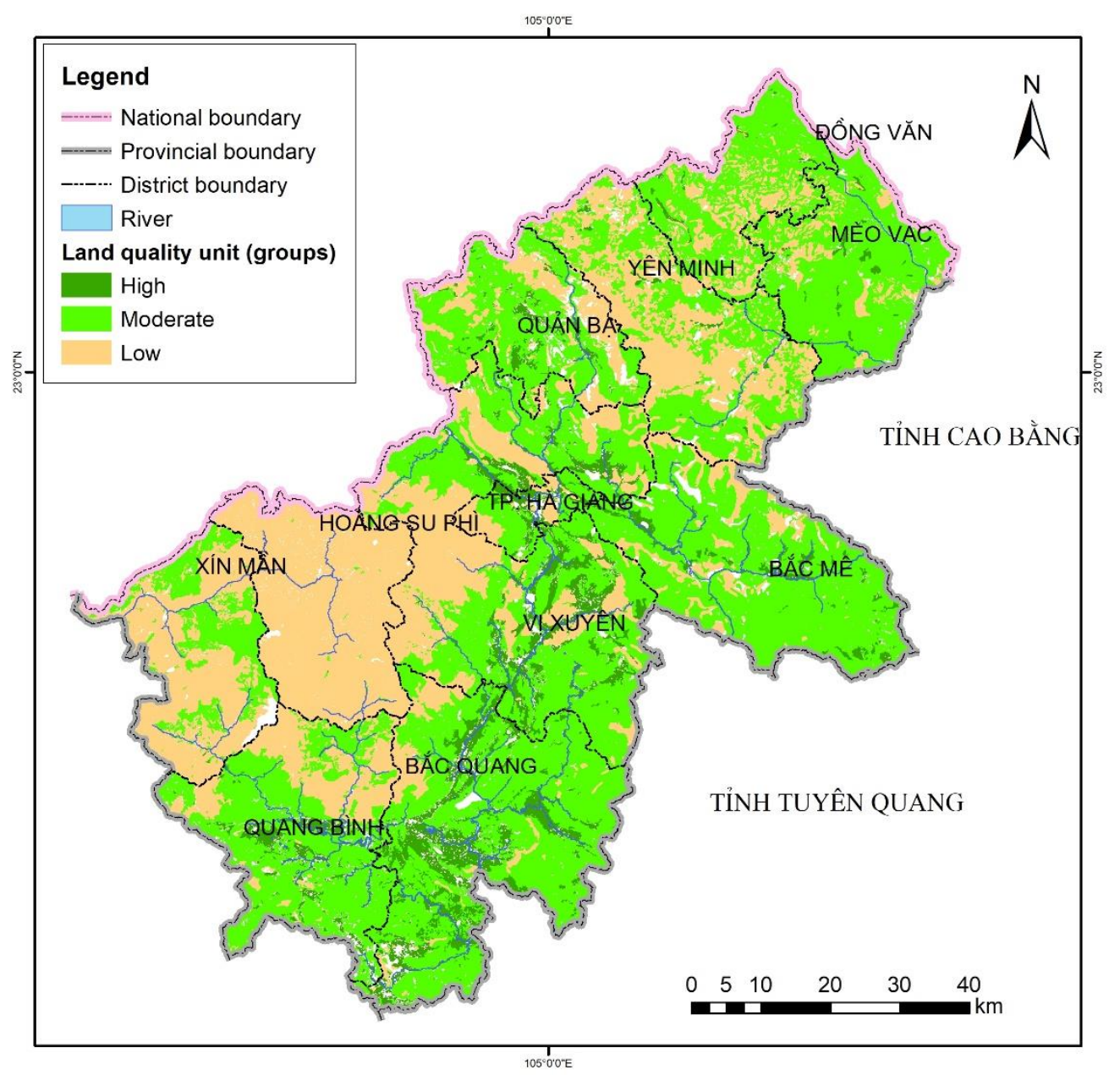

Figure 9. Land quality. 


\section{Conclusion}

The land quality result as $>60 \%$ land area of Ha Giang is moderate and high quality, it means the potential of agriculture development of this province is quite promising. It needs more investigation to evaluate the suitable cultivation crops, techniques, and policies to boost agriculture productivity in this province with high respect for sustainable development goals.

The GIS processing and land database are important tools in land quality evaluation. The result of the Land evaluation process can be stored, presented, and further analysis with GIS. It shows not only the highest potential using of GIS in land evaluation but also essential need of GIS technology in this field of study. In the research, the result is stored, organized in GIS database is useful in further study of land evaluation. The maps and data in GIS database can be use in agriculture cultivation planning or land use planning of the province.

\section{Author contributions}

The first author, Anh Mai Thi Tran setup the idea of the paper; Quan Anh Duong finalized the paper; other authors contributed the soil analysis and paper contents.

\section{References}

Ali, S., Techato, K., Taweenkun, J., Gyawali, S., (2018). Assessment of land use suitability for natural rubber using GIS in the U-tapao River basin, Thailand. Kasetsart Journal of Social Sciences (2018): 1-8.

Biali, G., Florian, S., (2013). Application of GIS technique in land evaluaiton for agricultural uses. Environmental engineering and management journal 12(4): 821-828.

Dedeoğlu, M., Dengiz, O., (2019). Generating of land suitability index for wheat with hybrid system aproach using AHP and GIS. Computers and Electronics in Agriculture (167): 105062.

Dijkerman, J. C., (1988). An Ustult-Aquult-Tropept Catena in Sierra Leone, West Africa, II. Land Qualities and Land Evaluation. Geoderma (42): 29-49.
FAO, (1976). A framework for land evaluation, FAO,." (Online). Available: http://www.fao.org/ 3/x5310e/x5310e00.htm.

FAO, (1997). Land Quality Indicators: Aspects of Land Use, Land, Soil and Plant Nutrients. FAO (Online). http://www.fao.org/3/W4745E/w47 45e0b.htm\#land quality indicators: aspects of land use, land, soil and plant nutrients.

FAO, (2007). Land evaluation: Towards a revised framework. (Online). Available: http://www. fao.org/3/a-a1080e.pdf

People's Committee of Ha Giang Province (2018). Ha Giang annual statistical reports.

Hossain, M. S., Das, N., (2010). GIS-based multicriteria evaluation to land suitability modelling for giant prawn (Macrobrachium rosenbergii) farming in Companigonj Upazila of Noakhali, Bangladesh. Computers and Electronics in Agriculture 70(1): 172-186.

Kazemi, H., Akinci, H., (2018). A land use suitability model for rainfed farming by Multicriteria Decisionmaking Analysis (MCDA) and Geographic Information System (GIS). Ecological Engineering Journal 116: 1-6.

Lam, V. T., Tran, T., and Ho, H. L., (2020). "Soil and Water Quality Indicators of Diversified Farming Systems in a Saline Region of the Mekong Delta, Vietnam." Agriculture (Switzerland) 10 (2). https://doi.org/10.3390 /agriculture10020038.

Lefroy, R. D. B., Bechstedt, H. D, and Rais, M., (2000). "Indicators for Sustainable Land Management Based on Farmer Surveys in Vietnam, Indonesia, and Thailand." Agriculture, Ecosystems and Environment 81 (2): 137-46. https://doi.org/10.1016/S01678809(00)00187-0.

Mazahreh, S., Bsoul, M., Hamoor, A. D., (2019). GIS approach for assessment of land suitability for different land use alternatives in semi arid environment in Jordan: Case study (Al Gadeer Alabyad-Mafraq). Information Processing In Agriculture (6): 91-108.

MONRE., (2015). "Technical framework of land survey and evaluation" 
Nguyen, N. D., Lei Guo Ping, and Le, P. C. L., (2018). Land Unit Mapping and Evaluation of Land Suitability for Agro - Forestrye in Thua Thien Hue Province - VietNam as an Example. IOP Conference Series: Earth and Environmental Science 159 (1). https://doi.org/10.1088/ 1755-1315/159/1/012012.

Nguyen, T. S., and Rajendra P. Shrestha, (2008). GIS Assisted Land Evaluation for Agricultural Developmwnt in Mekong Delta, Southern Vietnam. Journal of Sustainable Development in Africa 10 (2): 875-95.
Pham, G. T., Nguyen, T. H. and Kappas, M., (2018). Assessment of Soil Quality Indicators under Different Agricultural Land Uses and Topographic Aspects in Central Vietnam. International Soil and Water Conservation Research 6 (4): 280-88. https://doi.org/10. 1016/j.iswcr.2018.08.001.

Wang, D. C., Li, C. J., Song, X. Y., Wang, J. H., Yang, X. D., Huang, W. J., Wang, J. Y., Zhou, J. H., (2011). Assessment of Land Suitability Potentials for Selecting Winter Wheat Cultivation Areas in Beijing, China, Using RS and GIS. Agricultural Sciences in China 10(9): 1419-1430. 